\title{
Earnings Quality, Asymmetric Information, and Market Response : Insights from Indonesia \\ Puji Wibowo ${ }^{* 1}$, Etty Murwaningsari ${ }^{2}$ \\ ${ }^{* 1}$ Faculty of Economics and Business, Trisakti University and Lecturer of Polytechnic of State Finance STAN, Indonesia \\ ${ }^{2}$ Faculty of Economics and Business, Trisakti University, Indonesia
}

\author{
Article Info \\ Volume 7, Issue 6 \\ Page Number: 377-395 \\ Publication Issue :
}

November-December-2020

\section{Article History}

Accepted : 15 Dec 2020

Published : 29 Dec 2020

\section{ABSTRACT}

This study aims to investigate the impact of earnings quality and asymmetric information on market reaction which is proxied by cumulative abnormal return (CAR). This study also attempts to analyze whether good governance is playing an important role in moderating the effects of those two independent variables on CAR. By using purposive sampling method, this study covers 125 manufacturing companies listed on Indonesian Stock Exchange for 2017-2018 period to reveal above agenda. By using generalize least square (GLS) fixed effect model, it is found that reported earnings on financial statement have meaningful information for investors. By this, investors could expect stock return by relying on this earning information. Meanwhile, asymmetric information also matters for investors to make decisions regarding stock transaction. However, independence commissioner which is predicted to have an important role for stock performance, is not proved as moderating variable in this study.

Keywords: Asymmetric Information, Cumulative Abnormal Return, Earnings Quality, Independence Board

\section{INTRODUCTION}

The essence of earnings information for financial statement users is a long-standing debate in the last decades. Since the results of research by Ball and Brown (1968) and Beaver (1968) were published, various literature studies have examined the relevance of book value, income and cash flow. Many studies, as reported by Ahmadi and Bouri (2018), explain that book value and earnings have significant information content in equity valuation (Ohlson, 1995; Feltham and Ohlson, 1995; Easton, 1999). In particular, prior studies such as Dechow et al.'s (1999) and Landman and Maydew's (2002) show that earnings have higher value relevance and more information content compared to cash flows, because accrual accounting argues for better expectations about forecasts. cash flow rather than predictions about current cash receipts and payments. All these studies have been undertaken in several developed countries. However it might be the case that developing countries provide different perspectives.

Various studies evaluating the value relevance in emerging markets can be found in Ariff and Cheng (2011), Tamer (2014), Murni et al. (2015) and Qu and 
Zhang (2015), Chen et al. (2001), Haw et al. (2001), Hellström (2006), Papadaki and Siougle (2007), Mandilas et al. (2009); Pirie and Smith (2008); Filip and Raffournier (2010). Overall, with few inconsistent results, empirical studies confirm the existence of value relevance of accounting information (Mostafa, 2016). In Indonesia so far, we can see studies of value relevance of accounting, among others, from Murwanngsari et al. (2015), Machdar et al. (2017), Ardila and Setiawan (2018), Aryati and Wibowo (2017) and Suhardianto et al. (2017). In general, accounting information such as profit, other comprehensive income, and earnings per share has a relationship with stock returns and company performance.

The issue of earnings information in Indonesia has become more popular recently because of the national level incident of earnings management scandal committed by two state-owned companies, namely PT Garuda Indonesia (Persero) and PT Jiwasraya Insurance (Persero). The two companies reported their respective profits in the 2018 and 2019 financial statements, while in contrast this announced financial performance far from the true income. These two firms are suspected of engaging in earnings management practices in the form of early revenue recognition or other improper record according to financial accounting standards. The issue of earnings information for the two state companies leaves a big question of how good the quality of earnings reported by companies in Indonesia, especially public companies that list their shares on the capital market. National media reported that the Garuda and Jiwasraya cases had caused stock trading on the stock exchange to tend to slow down at the end of 2019 to early 2020. These two earnings management incidents revealed by independence commissioners, especially, those who supervise PT Garuda Indonesia (Persero).
Lessons learned from those two scandals are earnings information impact and corporate governance issue. Unreliable information provided in financial reports may lead to the wrong message to users of financial statements. The emergence of this information gap is caused by a conflict of interest between managers and shareholders, which reflects conditions asymmetric information (Leland and Pyle, 1977). Information asymmetry could also occur when company directors have better personal information than shareholders who have minimal information and clarity about the performance of a company in the financial market (Machdar, M, \& Murwaningsari, 2017). The share price in principle reflects information from various market participants who do not have information communication with the company. Thus, earnings quality matters in determining share price fluctuation.

The empirical findings revealed by Ady and Mulyaningtyas (2017) on the Indonesia Stock Exchange show that the level of investors' profits is obtained only by using very low technical analysis and even losses. Their study show that the efficiency level of the Indonesian capital market is at the lowest level (weak-form efficiency). But on the other hand, it is still possible to obtain benefits from published data, showing the level of efficiency of the Indonesian capital market is not yet efficient in a semi-strong form. This phenomenon indicates that the asymmetric information factor plays an important role in making investment decisions by Indonesia investors.

The second lesson from Garuda and Jiwasraya scandals is a challenge in improving good corporate governance (GCG). The issue of GCG has become the focus of increasing attention not only to directors, investors and stakeholders, but also regulators, all of whom are monitoring more and more carefully whether organizations are "regulated" efficiently, effectively and ethically (Demirbas and Yukhanaev, 
2011). The purpose of GCG is to minimize agency problems between managers and shareholders. In addition, Siagian (2011) explains that GCG can force managers to disclose important information so that information asymmetry between managers and shareholders can be minimized. One important component to support the supervisory function of the board of directors and to prevent poor financial reporting is the existence of an independent board (Siagian, 2013). The existence of independent commissioners in Indonesia is quite interesting to examine considering that many commissioner positions are filled by government officials, former government officials or people with political connections to government power holders. How big is the role of the commissioner who has been appointed as the independent commissioner in promoting good corporate governance. The case of manipulation of the financial statements of PT Garuda Indonesia (Persero) which was found by the independent commissioner shows that the role of the independent commissioner deserves further investigation.

This study attempts to analyse stock return volatility responding income announcement by incorporating asymmetric information in our model. We also consider the role of independent commissioners in promoting financial statement and reduce asymmetric information. Cumulative abnormal return (CAR) will be used as a proxy for the dependent variable of market reaction or market response in our analysis. The first independent variables in our study is earnings quality because the measurement rely on various financial statement indicators. Meanwhile, another explanatory variable is an asymmetric information. According to Suhardianto et al. (2017) this variable has not been widely used in research during the first ten years of the millennium. In addition, this study will use the independent commissioner variable as a moderating variable. The choice of one of the elements of corporate governance as a moderating variable, among others, is because this variable is still rarely used in this period of time as research by Suhardianto et al (2017). Research that has used independent commissioners as a moderating variable in the period after 2010 includes Siagian (2011 and 2013), Ajiwanto and Heriwati (2016), Kristanti (2016), Salipadang et al. (2017), Clarissa and Rasmini (2018), Manse (2018), Tanjung (2019), Kusumaningtyas and Murwaninsari (2020). Considering that the use of the independent commissioner variable is very diverse and presents inconsistent results, the use of this variable in this research must be valuable.

Our study focuses on manufacturing listed companies in Indonesian Stock Market in 2017-2018 period. In Indonesia, furniture companies were recorded to have contributed $19.6 \%$ of total GDP at the end of 2019 . The manufacturing sector is the cornerstone of the economy in Indonesia because it managed to provide the largest contribution among other sectors. The performance of listed manufacturers in the manufacturing industry dominates the Indonesian capital market. For example, share issuers from PT Astra Otopart Tbk, PT Gudang Garam Tbk are quite dominant in the stock market (Sri Artini \& Sandhi, 2020).

By adopting GLS panel regression analysis, this study contributes in supporting established literature concerning accounting information and asymmetric information roles. However, the moderating effect of independence board on market reaction in Indonesia is still questionable

The organization of this document is as follows. In Section 2 (Literature Review), I will give detail of any theory and previous studies to develop hypothesis. In Section 3 (Data dan Methods), present our data dan methods to analyse. In Section 4 (Results and Discussion), we present our hypothesis test and 
interpret the results. Finally, Section 5 (Conclusion) is the last part of our paper, presents implication, limitation and suggestion for further research.

\section{LITERATURE REVIEW}

\section{Capital market theory}

The efficient capital markets theory was first introduced by Fama (1970) and became the most debatable topic in the modern finance literature. The theory in principle explains that the ideal capital market is one in which prices provide accurate signals for resource allocation: that is, a market where firms could make investment-production decisions, and investors may choose between portfolio investment decisions. Securities that represent company ownership should "fully reflect" all available information. Markets in which prices always "fully reflect" the information available are called "efficient". The share prices is formed by perception of investors towards firms performances, whereas financial reporting provide those kind of information. Value relevance of accounting information depends on quality of financial statements prepared by company managements. On the other hand, firm performances are basically associated with certain figures in the financial statements. Therefore, company directors have an interest and motivation to manipulate financial reports in resulting company profits as desired by shareholders. This behavior is an agency problem as revealed by Jensen and Meckling (1976).

Earnings quality accurately reflects company achievement (Demerjian et al., 2013) and provides more information about firm performance features that are relevant to certain decisions (Dechow et al., 2010). Aryati and Wibowo (2017) explain that signal theory describes how a company should provide signals to users of financial statements. The signal providing information about the condition of the company to the owner or other interested parties (investors). Financial reports published by the companies give investors signals about the company's future prospects. Investors' expectations of public enterprises therefore can be seen from their response towards investment decision in those companies.

\section{Prior Studies and Hypothesis Development}

One of the significant roles played by financial information published in the capital market is when facing the globalization of capital flows (Viador, 2011). Published financial data serves the purpose of providing information to facilitate the flow of capital from international investors as well as demonstrating the management of the resources entrusted to them (Van Greuning, 2009). Compliance with International Financial Reporting Standards also ensures that the data is relevant, has predictive value, is an accurate representation of material facts, is free from bias, and can be verified (Van Greuning, 2009).

Research on how investors respond to information in financial reports can be found in numerous literatures. Inspired by the research of Ball and Brown (1968) and Beaver (1968), various studies have been conducted to test the usefulness of accounting information for capital market players. Davis et al. (2012) and Demers and Vega (2014) tested the tone in earnings announcements and found that the tone associated with company performance and the market reacted positively to the tone expressed in earnings announcements. Earnings announcements have been characterized as the most visible and timely channel for managers to communicate quarterly operational performance (Davis and Tama-Sweet, 2012).

The accounting information published by the capital market issuers, of course, has brought multi reactions from financial reporting users, especially investors. The reaction of investors shows that accounting 
information has good relevance value. This confirms the study of Dechow et al. (1999) who revealed that earnings quality can predict expected future cash flows better than the value of operating cash flows and the difference varies with the company's operating cycle. In contrast, Francis and Schier (1999) show that the value relevance of income has decreased over the study sample period, whereas book value has increased. Landsman and Maydew (2002) found that the content of earnings information has not decreased by testing normal trading volume and abnormal return volatility. We can also find this explanation in a study by Ahmadi and Bouri's (2017).

Basu (1997) states that negative earnings are less persistent than positive earnings, and that the earnings response coefficient is larger for positive earnings than for negative earnings. Collins et al. (1997) tested the usefulness of earnings and book value for US firms between 1953 and 1993. These scholars determined that the shared predictability of book value and expected earnings would increase gradually over a longer period of time. In line with Collins et al. (1997), Gjerde et al. (2005) found that financial reporting is very beneficial for market players who trade on the Oslo Stock Exchange over a 40 year period. Moreover, Beisland (2009) found that book value of equity and income are generally related to stock prices and stock returns.

Study on quality and earnings management, especially those related to company performance, has been increasingly encouraged since the adoption of IFRS. With the adoption of a set of widely accepted accounting standards, it is hoped that it will increase the ability to compare financial reports provided by accounting rules carried out by various countries (Firmansyah and Irawan, 2019). Earnings quality is different from earnings management. Good earnings quality indicates the lack or absence of earnings management or engineering carried out by the company. By contrast, the higher the earnings management, the lower the earnings quality in a financial report.

Mostafa (2016) explains that a large amount of empirical evidence from developed countries (for example the United States and United Kingdom) has shown that income, cash flow, and book value have value relevance (Easton and Harris, 1991; Strong, 1993; Dechow, 1994; Collins. et al., 1997; Lev and Zarowin, 1999; ElyandWaymire, 1999). Therefore, they are considered a helpful measure to assess the current and future performance of the company. With respect to emerging markets and transition economies, relatively few studies have examined the value relevance of accounting information. For example, in China, Chen et al. (2001) reported the relevant of accounting value, despite the fact that the market was relatively immature, and adequate financial reporting was not available at that time. In the Czech Republic, Hellström (2006) investigated the value relevance of financial accounting information for Czech and Swedish companies. This study finds that accounting information has value relevance in the Czech Republic and that value relevance increases over time in consequence of the transition progress. However, accounting information is less relevant to value in the Czech Republic (transitional economy) than it is in Sweden.

Ahmadi and Bouri (2017) found that earnings and book value are positively correlated with firm value on the Tunisian stock exchange. This phenomenon is also found in the Egyptian stock exchange by Mostafa (2016) who found that earnings have a relevant value in explaining security returns. Meanwhile, Badu and Appiah (2018) found a positive relationship between earnings and book value and stock prices on the Ghana stock exchange. Meanwhile, Akram et al., (2015) are in line with the research results of Mahrani and Soewarno (2018) which revealed a negative effect 
of earnings management on the company's financial performance. On the contrary, Ma and Ma (2017) found that low earnings quality will be accompanied by high financial performance of public companies in China. The opposite result shows that better earnings quality will be associated with lower fluctuations in stock returns on the Japanese stock exchange (Mitra, 2016). The results of studies on the role of earnings quality in the investment decision-making process are varied and not yet conclusive. This encourages further research on the effect of earnings quality on investors' reactions in the stock market.

The reaction of financial reporting users regarding accounting information, especially earnings, can be seen from stock returns, both normal and abnormal returns. Abnormal returns are increased on earnings announcements after controlling for risk (Dumontier and Raffournier, 2002). Abnormal returns can be obtained within a certain number of days around the announcement date of earnings, and earnings announcements have some impact on the performance of shares on the Ho Chi Minh stock exchange (Corrado and Zivney, 1992). We can also find findings regarding the positive response of investors to earnings announcements in Sehgal and Sijoy (2011) in researching investor behavior in the Indian capital market and Syed and Bajwa (2017) in observing the stock exchange in Saudi Arabia.

Based on these considerations, the first hypothesis proposed in this study is:

\section{H1: earnings quality has a positive effect on market reaction.}

If the quality of earnings is measured by discretionary accruals, this earnings quality will have a negative effect on market reactions.

Meanwhile, the agency theory popularized by Jensen and Meckling (1976) suggests that the emergence of differences in interests between managers as agents and shareholders as principles is partly due to information gaps. Company managers who are given the mandate to manage company resources have superior information about the strengths and weaknesses of the company compared to shareholders. The main findings from study by Kong et al. (2011) on the behavior of investors on stock exchanges in China revealed that asymmetric information has a significant negative impact on the sensitivity of investment to stock prices; and asymmetric information has a significant positive impact on the sensitivity of stock prices to investment. Meanwhile, Ravi and Hong (2015) found that adverse selection costs from trade significantly reduce post-addition and increase post-write-off in the S\&P 500 index. Irrational concern is also an important factor in explaining fluctuations in stock market returns in companies listed in the S\&P 500 index (Soydemir et al., 2017). Information asymmetry broadly follows the same trend as volatility, with a higher sensitivity to market risk exposure (Tchamyou et al., 2018).

Research on the impact of asymmetric information on the behavior of issuers and investors in Indonesia, among others, is explained by Rachmawati (2010), Wiyadi et al. (2016), Machdar et al. (2017), Apriani and Wirawati (2018), Malau et al. (2019), Kusumaningtyas and Murwaninsari (2020). Inconsistent results can be found in the behavior of financial report compilers. Rachmawati (2010) did not find the effect of asymptomatic information on earnings management, while Wiyadi et al. (2016), Apriani and Wirawati (2018), Malau et al. (2019), Kusumaningtyas and Murwaninsari (2020) reveal the opposite. Machdar et al (2017) found an interesting phenomenon in capital market behavior where asymmetric information weakens the effects of earnings quality and conservatism on firm performance but strengthens the effect of real earnings management on firm performance. 
Kusumaningtyas and Murwaningsari (2020) reveal the influence of independent commissioners as a variable that weakens the positive effect of asymmetric information on the income smoothing process.

In a study on investor behavior on the Chinese stock exchange in 2006, Kong et al. (2011) found that asymmetric information has a significant negative impact on the sensitivity of investment to stock prices; and asymmetric information has a significant positive impact on the sensitivity of stock prices to investment. Information asymmetry usually refers to the inequality between the information held by market participants, which can influence investors' decision making. Studies conducted in China and other countries show that corporate earnings management is closely related to information. Both Dye (1988) and Trueman and Titman (1988) find that information asymmetry between shareholders and management is a necessary condition for the existence of earnings management. Research by Bhattacharya et al. (2008) concluded that the lack of information provided to investors makes it difficult for investors to process this information compared to investors who have more information. This situation gives rise to information asymmetry. Ravi and Hong (2015) found a positive relationship between abnormal returns and increased costs arising from adverse selection. This is in line with research by Elliott et al., (2006), Green and Jame, (2011).

Therefore, the second hypothesis developed in this study is:

H2: asymmetric information has a positive effect on market reaction.

Meanwhile, independent commissioners are one of good governance elements and are an interesting variable in this study because they are expected to improve the financial reporting quality as well as reduce the information gap between management and external stakeholders. It is expected that problems arising from the existence of agency between management and company holders can be mitigated by complying with the provisions of good corporate governance.

Ji et al., (2015) found that the promulgation of corporate governance reforms in 2002 had a positive impact on the quality of revenues of listed companies in China. Lin and Hwang (2010), Messier et al., (2008); Liu and $\mathrm{Lu}$ (2007) illustrate that corporate governance can reduce earnings management. Meanwhile, AlThuneibat et al., (2016) did not find any significant influence of corporate governance on earnings management.

Siagian and Trenaningsih (2011) in their research on the impact of independent commissioners and audit committees in Indonesia during 1999 to 2004 period found that earnings management (discretionary accruals) were significantly lower in the first and second years after the company met the JSE independence requirements. These results indicate that the Indonesian Stock Exchange (IDX) regulations requiring independent commissioners and audit committees have proven effective in improving earnings quality by reducing total earnings management in the first and second years after the year the IDX requirements are fulfilled. The same thing was also expressed by Manse (2018) on the IDX in a different period, namely 2014-2017 for mining companies. This finding is also confirmed by Alzoubi (2014) in his research on issuers on the Jordanian stock exchange. Thus, independent commissioners are considered to have a good influence in preventing earnings management and increasing stock returns.

In accordance with the postulate in agency theory, the existence of independent commissioners should reduce the conflict between management and shareholders. In general, independent commissioners 
carry out the role of experienced professionals in other companies or large organizations and therefore, care about their reputation (Nguyen and Nielsen, 2010). Fama and Jensen (1983) also note that the majority of independent boards are managers or decision makers who care about their reputation. Luan and Tang (2007) found that the appointment of directors outside the board of directors is positively related to firm performance. Therefore, independent directors are expected to be professional and able to protect the interests of shareholders and other users of financial reports by monitoring the financial reporting system. Furthermore, directors and audit committees that are independent of management must improve the company's reporting system and the quality of reported earnings because they are not subject to potential conflicts of interest which reduce their monitoring capacity (Siagian and Tresnaningsih, 2011).

Based on these considerations, the third hypothesis proposed in our study is:

H3: independent commissioners moderate the positive effect of earnings quality on market reactions.

On the other hand, the existence of independent commissioners may not have a positive effect on company performance in the event of asymmetric information. The results of research by Nguyen and $\mathrm{Lu}$ (2017) reveal that independent directors / commissioners have an overall negative effect on the company's operating performance. This finding could be due to information asymmetry, untapped independent board expertise, and a dominance of ownership concentration that prevents independent boards from fulfilling their monitoring of governance functions. Meanwhile, Kusumaningtyas and Murwaningsari (2020) found that independent commissioners were proven to weaken the positive effect of information asymmetry on earnings management efforts in the form of income smoothing.

Based on the above considerations, the fourth hypothesis in this study is:

H4: independent commissioners moderate the positive effect of asymmetric information on market reactions.

In the light of the development of the above hypothesis, we can see the framework in this study in Figure 1 as follows.

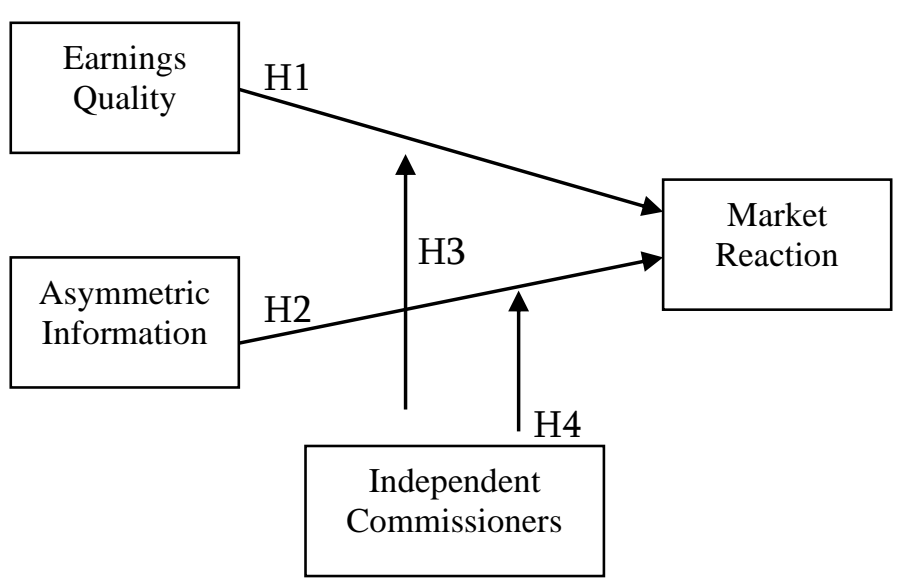

Figure (1): Conceptual Framework

\section{III.DATA AND METHODS}

This study is a quantitative research that uses hypothesis testing to measure the effect of earnings quality and asymmetric information on market reactions with the presence of independent commissioners as moderation. The data used is secondary data which is mainly obtained from the Indonesia Stock Exchange. These data are obtained from the IDX website at www.idx.co.id, as well as from the websites of each company.

The unit of analysis in this study is a public company listed on the Indonesia Stock Exchange (IDX) during the 2017-2018 period. The population in this study 
were all manufacturing companies listed on the IDX as of December 31, 2018. The research sample was taken using the purposive sampling method with the following criteria:

1. The company publishes financial reports within the period of observation.

2. The company's transactions are not being frozen by the capital market authority.

3. The company has independent commissioners.

4. The company actively trades in shares

The dependent variable developed in this study is the market reaction (market response), which is how investors respond to financial information and other information they receive. In this study, the market reaction is represented by the cumulative abnormal return (CAR) indicator.

According to Syed and Bajwa (2018), abnormal return is calculated by subtracting the normal return of shares from the actual return of each share through the event window. The measurement of abnormal return further adopts the Jones (1999) model as adopted by Murwaningsari (2008) as follows.

$$
\mathrm{ARit}=\mathrm{Rit}-\mathrm{Rm}, \mathrm{t}
$$

where,

ARit = abnormal return of company shares $\mathrm{i}$ in period $\mathrm{t}$

Rit = actual return of company shares $\mathrm{i}$ in period $\mathrm{t}$

$\mathrm{Rm}, \mathrm{t}=$ market return in period $\mathrm{t}$

Meanwhile, the actual return on the company's shares as described by Murwaningsari (2008) and Sir, Subroto, and Chandrarin (2010) is as follows:

$$
\mathbf{R}_{\mathrm{it}}=\frac{\mathrm{P}_{\mathrm{it}}-\mathrm{P}_{\mathrm{it}}-1}{\mathrm{P}_{\mathrm{tt}}-1}
$$

Where,

Rit $=$ actual return of company $i$ shares in period $t$

Pit $=$ share price $i$ in period $t$;

Pit-1 = share price $\mathrm{i}$ in period $\mathrm{t}-1$
Furthermore, Murwaningsari (2008) and Sir et al (2010) also explain that market returns can be calculated by observing the dynamics of the Composite Stock Price Index during the observation period, using the formula below:

$$
\mathrm{Rm}_{\mathrm{t}}=\left(\mathrm{IHSG}_{\mathrm{t}}-\mathrm{IHSG}_{\mathrm{t}-1}\right) / \mathrm{IHSG}_{\mathrm{t}-1}
$$

where:

$\mathrm{Rm}_{\mathrm{t}} \quad=$ daily market returns

IHSG $_{\mathrm{t}}=$ composite stock price index on day $\mathrm{t}$ IHSG $\mathrm{t}-1=$ composite stock price index on day $\mathrm{t}-1$

Moreover, CAR is calculated based on the accumulated abnormal return for 11 days of observation, namely the day $\mathrm{D}$ when the issuer's financial report is submitted to the stock exchange, D-5 and $\mathrm{H}+5$. This is according to the calculations described by Murwaningsari (2008) and Sir et al (2010) with the following formula:

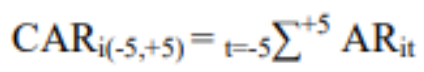

where;

- $\operatorname{CAR}_{\mathrm{i}}(-5,+5)$ : cumulative abnormal return of company $i$ during the observation period of approximately 5 days from the date of publication of the financial statements, namely 5 days before, 1 day of publication date and 5 days after the date of submission of financial reports to the Financial Services Authority)

- ARit: company i's abnormal return on day $t$

The independent variables used in this research are earnings quality and asymmetric information. Earnings quality shows how strong the value of accrual earnings reported in the current year can predict the amount of earnings in the following year. The measurement of earnings quality used in this research uses the discretionary accruals model developed from the Jones model by Kothari (2005) as follows: 
accuals $=a\left(\frac{\overline{1}}{\text { TAt }-1}\right)+b \frac{\Delta \text { salest }}{\text { TAt }-1}+c \frac{P P E t}{T A t-1}+d R O A t+\epsilon t$

Accruals are calculated from income before extraordinary minus cash flows from operations in year $t$ divided by total assets in year $t-1$. The equation above is cross-sectional estimated each year to produce expected (non-discretionary) accruals. The difference between observed value and fitted value is that the residual / error is discretionary accruals. This model has been used by Firmansyah and Herawati (2016) and many others. The lower the accrual quality score, the better the reported earnings quality and the higher the accrual value represents the poor quality of reported earnings (Lymo 2014).

The asymmetric information variable is measured using a proxy used in the research of Machdar et al. (2017). This model has previously been used in the research of Callahan et al. (1997). The proxy for the asymptomatic information is the bid-ask spread (BAS) with the following formula:

$$
\text { BAS }_{\text {it }}=\Sigma\left(\text { Ask }_{\mathrm{it}}-\text { Bid }_{\mathrm{in}}\right) / \Sigma\left(\left(\text { Ask }_{\mathrm{n}}+\text { Bid }_{\mathrm{it}}\right) / 2\right.
$$

where,

BASit = spread between the ask (ask) and the bid (bid) divided by the amount from supply and demand are divided into two;

Askit $=$ the highest asking price of company i's shares in year $\mathrm{t}$;

Bidit $=$ the lowest bid price for my company's shares in year $\mathrm{t}$.

The moderating variable used in this study is the independent commissioner. This variable is measured by comparing the number of independent commissioners with the total number of commissioners in the observed company. This formula has been used in several previous studies, such as Kusumaningtyas and Murwaningsari (2020) and Fauzyyah \& Rachmawati, (2019) with the following formula:
Independent commissioners $=$ (number of independent commissioners/total commissioners) $\mathrm{X}$ $100 \%$

In addition, this study also uses several control variables which are empirically proven to be the determinant factor of market reactions. Some of these control variables are firm size (Atiase and Bamber, 1994; Luo and Zhuo, 2017, Horton and Serafeim, 2010; Cormier, 2013), growth (Aryati et al, 2017; Pakpahan, 2010), and leverage (Gunasekarage and Reed , 2008, Aryati et al., 2017 and Harahap, 2010).

Thus, the model to be used in this study consists of two models as follows:

\section{Model 1 (without moderating variable)}

$\mathrm{CAR}_{\mathrm{it}}=\beta 0_{\text {it }}+\beta 1 \mathrm{EQ}_{\mathrm{it}}+\beta 2 \mathrm{AI}$ it $+\beta 5$ Leverage it $+\beta 6$ Firmsizeit $+\beta 5$ Growth $_{\text {it }+\varepsilon_{\text {it }}}$

\section{Model 2 (with moderating variable)}

$\mathrm{CAR}_{\text {it }}=\beta 0_{\text {it }}+\beta 1 \mathrm{EQ}_{\mathrm{it}}+\beta 2 \mathrm{AI}{ }_{\mathrm{it}}+\beta 3 \mathrm{EQ}^{*} \mathrm{IC}_{\mathrm{it}}+\beta 4 \mathrm{AI}^{*} \mathrm{IC}_{\text {it }}+$ $\beta 5$ Leverage $_{i t}+\beta 6$ Firmsize $_{i t}+\beta 7$ Growth $_{i t}+\varepsilon_{\mathrm{it}}$

Where,

- $\mathrm{CAR}_{\mathrm{it}}=$ market reaction as measured by cumulative abnormal return;

- $\mathrm{EQ}_{\mathrm{it}}=$ quality of company $\mathrm{i}$ earnings in year $\mathrm{t}$, as measured by discretionary accruals;

- $\mathrm{AI}_{\mathrm{it}}=$ asymmetric information on company $\mathrm{i}$ in year $t$, which is measured by the spread between the bid price and the ask price;

- $\mathrm{IC}_{\mathrm{it}}=$ proportion of independent commissioners to the total number of commissioners at company $i$ in year $\mathrm{t}$;

- Leverage $_{\text {it }}=$ ratio between total debt and equity (debt-to-equity ratio) in company $i$ in year $t$; 
- Firmsizeit $=$ firm size $\mathrm{i}$ in year $\mathrm{t}$ which is calculated using the natural logarithm of the company's total assets;

- Growth $_{\text {it }}=$ sales growth of company $\mathrm{i}$ in year $\mathrm{t}$ which is calculated by comparing changes in sales value in year $\mathrm{t}$ from year $\mathrm{t}-1$ (in percentage);

- $\varepsilon_{\mathrm{it}}=$ error component in the model for firm $\mathrm{i}$ in period $t$.

The data will be analyzed using multiple regression with a panel data approach because the observed data is cross-company and inter-period. Panel data analysis requires some testing first to choose the right panel model, namely whether to use common effects, fixed effects, and random effects. The classical assumption test is carried out when the model selected based on the test is common effect and fixed effect. As for the chosen random effect, according to Gujarati (2009), only need to analyze normality and multicollinearity.

\section{IV.RESULTS AND DISCUSSION}

\section{Statistic Descriptive}

Based on the sample selection criteria, 125 companies were obtained per year, so that the total number of companies observed was 250 company-years. Table I below presents descriptive statistics of the research data in question.

TABLE I

\section{STATISTIC DESCRIPTIVE}

\begin{tabular}{|c|c|c|c|c|c|c|c|}
\hline & CAR & $E Q$ & $\overline{\mathrm{Al}}$ & IC & LEV & SIZE & GROWTH \\
\hline Mean & 0.015604 & 0.001293 & 0.088814 & 0.413626 & 7.365100 & 7.696288 & 0.535959 \\
\hline Median & 0.012670 & .0 .001100 & 0.012200 & 0.375000 & 0.830000 & 7.711090 & 0.083410 \\
\hline Maximum & 0.510570 & 0.588800 & 2.000000 & 1.000000 & 1352.000 & 12.75050 & 100.7491 \\
\hline Ninimum & .0 .2111100 & .0 .195730 & 0.000500 & 0.000000 & .166 .7500 & 0.330000 & .0 .980100 \\
\hline Sta. Dev. & 0.089135 & 0.086143 & 0.329673 & 0.120045 & 86.95517 & 1.909661 & 6.387120 \\
\hline Obserasai & 249 & 249 & 249 & 249 & 249 & 249 & 249 \\
\hline
\end{tabular}

Based on the information in Table I above, we can see that the cumulative abnormal return (CAR) interval of all observed manufacturing companies ranged from minus $21.11 \%$ to $51.05 \%$ with an average of $1.56 \%$. This indicates a high gap between companies with good stock performance and companies that are less attractive to investors.

In terms of earnings quality, the discretionary accruals for manufacturing companies during the 2017-2018 period were quite low, namely an average of only $0.12 \%$. This means that most of the accrual value in the income statement is contributed by nondiscretionary accruals, which include depreciation of fixed assets. However, there are suspected companies to engage earnings management. This can be seen from the maximum value of discretionary accruals which reached $58.88 \%$ or higher than the nondiscretionary accruals.

On the other hand, the level of information that is asymmetrical is shown by the spread between the bid and ask prices of the shares offered on the stock exchange. High spreads indicate that investors have received incomplete information from the prospective investee company. Conversely, if the spread is relatively low, investors will get adequate information from the listed company. In general, the average spread is around $8.88 \%$ with the interval from the lowest level to the highest level being $1.22 \%$ to $200 \%$. This shows that the information on the stock exchange is still uneven, resulting in incomplete information from stock exchange players.

The existence of independent commissioners in manufacturing companies in Indonesia shows a variety of phenomena. Various firms have no independent commissioners at all. But on the other hand, there are also companies that are fully supervised by independent commissioners on the board. This is because all members of the board of commissioners come from professionals who are not affiliated with the interests of the company. On average, manufacturing companies in Indonesia have a good board of commissioners. This portrait is shown 
by the portion of independent commissioners which is more than 40 percent.

In the light of financial performance, manufacturing enterprises are unique with respect to leverage and growth. Turning to the ratio of debt to equity, the figures are very striking, namely the lowest is minus 166.75 times and the highest is 1.352 . It might be the case considering that many observed companies produce basic necessities that are consumed by the community, such as food, clothing and medicines. Companies that have high debt can survive if they are supported by a good sales turnover and cash flow. With an average sales growth value of $53.59 \%$, manufacturing companies in Indonesia seem confident enough to develop their business by relying on debt to external parties

\section{Correlation Analysis and Data Distribution}

Referring to the correlation analysis between independent variables, namely earnings quality (EQ), asymmetric information (AI), leverage (Lev), firm size (SIZE) and turnover growth (Growth), the result is that there is no correlation between them. This is because the correlation value between each variable is less than 0.8 (Table II). Therefore, multicollinearity was not found between the independent variables.

TABLE II

CORRELATION ANALYSIS

\begin{tabular}{|l|l|l|l|l|c|}
\hline & EQ & AI & Lev & Size & Growth \\
\hline EQ & 1.000 & -0.024 & 0.350 & 0.032 & 0.017 \\
\hline AI & -0.024 & 1.000 & 0.006 & -0.046 & -0.020 \\
\hline Lev & 0.350 & 0.006 & 1.000 & -0.063 & -0.007 \\
\hline Size & 0.032 & -0.046 & -0.063 & 1.000 & -0.025 \\
\hline $\begin{array}{l}\text { Grow } \\
\text { th }\end{array}$ & 0.017 & -0.020 & -0.007 & -0.025 & 1.000 \\
\hline
\end{tabular}

Turning to an observation of data normality, the Jarque Berra coefficient shows the number 813.1581 with a probability of 0.000 . This shows that the observed data do not tend to be abnormal. However, the data of this study can be considered normally distributed according to the Central Limit Theorem (CLT) theory. Gujarati \& Porter (2010) explain that based on CLT, research with a large number of observations tends to have a normal data distribution. According to Gujarati \& Porter (2010), data is considered large if it reaches 100 or more observations. In this regard, the data in this study have a total of 244 observations so that the residuals of this research data can be considered normally distributed.

\section{Hypothesis Testing}

The authors eventually test the hypothesis on model 1 and model 2 by adopting the fixed effect model (FEM) with a generalized squared (GLS). Model 1 consists of CAR as the dependent variable, EQ and AI as independent variables and LEV, SIZE, and Growth as control variables. The model 2 is run by running model 1 and incorporated with the independent commissioner (IC) as a moderating variable. By using the FEM model and the fixed GLS cross section approach for model 1 , the results are as presented in Table III below.

TABLE III

FEM REGRESSION ANALYSIS (GLS) DEPENDENT VARIABLE : CAR (MODEL 1)

\begin{tabular}{|c|c|c|c|}
\hline Variables & $\begin{array}{c}\text { Predictio } \\
\mathbf{n}\end{array}$ & Coefficient & Sig. \\
\hline EQ & - & -0.1195 & $0.000^{* * *}$ \\
\hline AI & + & 0.033 & $0.000^{* * *}$ \\
\hline Lev & - & $0.4 .31 \mathrm{E}-06$ & 0.5574 \\
\hline SIZE & + & 0.0000 & 0.1030 \\
\hline Growth & + & -0.0045 & 0.0000 \\
\hline
\end{tabular}


*** means high significant (1\%). $R$-Square

(unweighted): 0.433; F Stat: 55,587

Earnings quality is measured in this study using discretionary accruals. The higher the discretionary accrual, the lower the profit quality, and vice versa. Therefore, the prediction of the earnings quality coefficient (EQ) is negative. This is still in line with the initial hypothesis which generally states that earnings quality is directly proportional to CAR. Asymmetric information is predicted to have a negative sign. The higher the gap between the information owned by the company and that obtained by investors, the worse the investor will react to the company's performance. Therefore, the realized stock returns are not in accordance with investors' expectations. For the control variable, although the hypothesis is not tested, based on previous empirical evidence, the level of leverage, company size, and sales turnover growth are estimated to have a significant effect on CAR.

Based on the results of hypothesis testing for model 1 as shown in Table 3 above, it can be seen that only the EQ variable supports the hypothesis (significant at the $1 \%$ level). Meanwhile, the AI variable also shows significant results (level 1\%), with the magnitude of the coefficient in accordance with the hypothesis. As for the control variables, none of them proved to be a determinant factor for the amount of CAR for manufacturing companies in Indonesia during the observation period. The result of the F-statistic is very good $(55,587)$. This shows that model 1 is a suitable model to be used in this research.

Meanwhile, by using panel data regression with period-fixed FEM and GLS for model 2, the test results are obtained as shown in Table IV below.
TABLE IV

FEM REGRESSION ANALYSIS (GLS)

DEPENDENT VARIABLE : CAR (MODEL 2)

\begin{tabular}{|c|c|c|c|}
\hline Variables & $\begin{array}{c}\text { Predictio } \\
\mathbf{n}\end{array}$ & $\begin{array}{c}\text { Coefficie } \\
\mathbf{n t}\end{array}$ & Sig. \\
\hline EQ & - & -0.1006 & 0.7184 \\
\hline AI & + & 0.0344 & 0.6990 \\
\hline EQ*IC & - & 0.2930 & 0.6758 \\
\hline EQ*IC & - & -0.0681 & 0.7471 \\
\hline Lev & - & $\begin{array}{c}1.281 \mathrm{E}- \\
05\end{array}$ & 0.8651 \\
\hline SIZE & + & -0.0004 & 0.0722 \\
\hline Growth & + & 0.0001 & 0.8675 \\
\hline
\end{tabular}

$R$-Square (unweighted): 0.077; F Stat: 2.533 (Prob $0.0115)$

Based on the test results in Table 4, we can see that none of the variables are significant. However, the Fstatistic for model 2 is 2.533 at a probability below $5 \%$, indicating that model 2 is a good formula.

\section{Discussion}

Referring to the results of hypothesis testing for model 1 , the company profits that are presented in the financial statements have beneficial aspects for decision makers, especially stock market players. Accrual quality in this research is represented by discretionary accruals. The more firms have discretion on the company's accrual accounting policies, the less reliable the information is for investors. Investors will respond to the earnings information presented in the financial statements by buying or selling company shares. Good accrual earnings information implies low earnings management practices or at least discretionary accruals. Thus, in general the earnings quality of manufacturing companies can provide benefits to investors by pursuing stocks with promising cumulative abnormal returns. 
The findings also confirm the phenomenal research results of Ball and Brown (1968) regarding earnings informativeness for decision makers. The results of this study support previous research by Ahmadi and Bouri (2017) which found that earnings and book value are positively correlated with company value on the Tunisian stock exchange. Mostafa (2016) and Badu and Appiah (2018) also found a similar relationship between earnings and book value and stock prices on the Ghana stock exchange. In addition, the results of this research are in line with the capital market efficiency theory, where investors respond to information that can be obtained in the capital market. Fama (1970) explains that capital market efficiency is considered a strong form of efficiency when all available public and private source information is fully reflected in stock prices.

On the other hand, asymmetric information also has an impact on CAR volatility for manufacturing companies during the financial statement issuance period. This is suspected, among others, because investors are brave enough to speculate in pursuit of high stock returns. The high level of asymmetric information creates high costs for investors to reduce the information gap between them and the listed company. The higher the costs incurred, it indicates that there are also high expectations of an increase in stock prices.

The results of this study on asymmetric information are in line with previous empirical evidence such as Ravi and Hong (2015), Kong et al. (2011), Dye (1988), Elliott et al., (2006), Green and Jame, (2011) who found the effect of asymmetric information on stock return fluctuations. Trueman and Titman (1988) who found that information asymmetry between shareholders and management is a necessary condition for the existence of earnings management. In addition, this result is different from that found by Kusumaningtyas and Murwaningsari (2020) which states that asymmetric information plays a role in income smoothing practice.

Finally, the results of testing model 2 show that independent commissioners fail to become a moderating variable in this research model. When model 2 accommodates independent commissioners as a moderating variable, none of the independent variables is statistically significant. This can be caused by several reasons as follows. First, the measurement of the independent commissioner variable, which is the percentage composition of independent commissioners to the number of commissioners in a company, may not be suitable for use in the Indonesian context. Thus, it is necessary to take other measurement methods into account that reflect more on the role of independent commissioners in guarding good corporate governance, such as the intensity of board meetings and the background and work experience of independent commissioners. Second, these results also show that it is possible that the role of independent commissioners in Indonesia is only limited to the administrative aspect. Independent commissioners are less able to develop their roles in escorting companies to improve financial accountability. Third, these results show that it is possible that good governance in Indonesia needs to improve, especially in relation to the effectiveness of the existence of independent commissioners.

\section{CONCLUSION}

The purpose of this study is to observe the impact of earnings quality and asymmetric information on market reactions represented by cumulative abnormal returns. This study also investigates the extent to which independent commissioners can strengthen or weaken the influence of two independent variables on CAR. Based on panel data regression testing with the FEM GLS model, evidence is obtained that earnings quality provides a signal for investors to 
make important decisions related to buying and selling shares on the stock exchange. This confirms the empirical evidence of Ball and Brown (1968) and a number of other researchers. Investors responded very well to the earnings presented in the financial statements. Therefore, the earnings information is considered to have relevance for decision making.

An asymmetric information has an impact on CAR fluctuations. This could be because investors in the stock exchange are brave enough to speculate by paying costs to reduce adverse selection. The role of independent commissioners, which is expected to strengthen the effect of earnings quality and reduce the impact of asymmetric information, cannot be proven in this research. This study result in consequence of good governance redesign irrespective of providing assurance for the quality of good financial reports.

This research has several limitations such as the measurement aspect of independent commissioners which only assesses in terms of quantity. Future research is expected to develop a measure of the effectiveness of independent commissioners which emphasizes the quality aspect such as number of meetings attended by commissioners and competency of the commissioners. This study observed a short period only. The time constraints faced by researchers are one of the obstacles for observing longer periods. The subsequent research is expected to accommodate other aspects of good corporate governance such as the role of the audit committee. It is expected that the aspects of leadership that are proven effective in maintaining organizational effectiveness can also be considered for future work.

\section{REFERENCES}

[1] Ahmadi, Ali and Bour, Abdelfettah. (2017). The accounting value relevance of earnings and book value: Tunisian banks and financial institutions. International Journal of Law and Management Vol. 60 No. 2: 342-354.

[2] Al-Thuneibat, A., Al-Angari, H. and Al-Saad, S. (2016). The effect of corporate governance mechanisms on earnings management: Evidence from Saudi Arabia, Review of International Business and Strategy, Vol. 26 (1): 2-32

[3] Ardila, Lina Nur dan Setiawan, Doddi. (2018). Relevansi Nilai Informasi Akuntansi: Studi Perbandingan Antara Perusahaan Bumn Dan Perusahaan Non-Bumn Yang Terdaftar Di Bursa Efek Indonesia. Jurnal Akuntansi dan Bisnis, Vol 18 No. 2:126-140.

[4] Ariff, M. and Cheng, F.F. (2011), "Accounting earnings response coefficient: an extension to banking shares in Asia pacific countries", Advances in Accounting, Vol. 27 No. 2, pp. 346-354.

[5] Aryati, Titik dan Indri Wulandari. (2014). Pengaruh Corporate Governance Dan Karakteristik Perusahaan Terhadap Earning Response Coefficient. FEB Universitas Trisakti Jakarta: Jakarta.

[6] Atiase, R.K. and L.S. Bamber, 1994, Trading volume reactions to annual accounting earnings announcements, Journal of Accounting and Economics 17, 309 329.

[7] Ball, R. and Brown, P. (1968), "An empirical evaluation of accounting income numbers", Journal of Accounting Research, Vol. 6 No. 2, pp. 159-17.

[8] Beaver, W.H. (1968), "The information content of annual earnings announcements", Journal of Accounting Research, Vol. 6, pp. 67-92. 
[9] Callahan, C.M., Lee, C.M., Yohn, T.L. (1997), Accounting information and bid ask spreads. Accounting Horizons, 11(4), 50-60.

[10] Chen, C.J.P., Chen, S. and Su, X. (2001). Is accounting information value-relevant in the emerging Chinese Stock Market? Journal of International Accounting, Auditing and Taxation, Vol. 10, pp. 1-22

[11] Cheng, Chia Ling dan Kung, Fan-Hua. (2015). The effects of mandatory corporate social responsibility policy on accounting conservatism. Review of Accounting and Finance, Vol.15 (1):2-20.

[12] Collins, D. and S. Kothari. (1989). A theoretical and empirical analysis of the determinants of crosssectional and intertemporal differences in earnings response coefficients. Journal of Accounting and Economics (July 1989): 143-82.

[13] Dechow, P.M.A., Hutton, P. and Sloan, R.G. (1999), "An empirical assessment of the residual income valuation", Model. Journal of Accounting and Economics, Vol. 26 No. 1-3:134.

[14] Demirbas, D. and Yukhanaev, A. (2011). Independence of board of directors, employee relation and harmonization of corporate governance. Empirical evidence from Russian listed companies. Employee Relations, Vol. 33 No. 4, 444-471.

[15] Easton, P. (1999). Security returns and the value relevance of accounting data. Accounting Horizons, Vol. 13, pp. 399-412

[16] Elliott, W.B., Van Ness, B.F. Walker, M.D. and Warr, R.S. (2006). What drives the S\&P 500 inclusion effect? An analytical survey. Financial Management, Vol. 35 No. 4, 31-48.

[17] Feltham, G. and Ohlson, J. (1995). Valuation and clean surplus accounting for operating and financial activities. Contemporary Accounting Research, Vol. 11 No. 2, 689-731.
Fama, E.F. (1970). Efficient capital markets: a review of theory and empirical work. Journal of Finance, Vol. 25 No. 2, 383-417.

[19] Filip, A. and Raffournier, B. (2010). The value relevance of earnings in a transition economy: the case of Romania. The International Journal of Accounting, Vol. 45, pp. 77-103.

[20] Firmansyah, Amrie dan Herawaty, Vinola. (2016). Pengaruh Income Smoothing, Kebijakan Dividen, Leverage dan Ukuran Perusahaan terhadap Earning Response Coefficient dan Future Earning Response Coefficient. Jurnal Informasi, Perpajakan, Akuntansi, dan Keuangan Publik, Vol. 11(1):31-48.

[21] Firmansyah, Amrie dan Irawan, Ferry. (2019). Do IFRS Adoption and Corporate Governance Increase Accounting Information Quality in Indonesia?. Accounting Analysis Journal, 8(1): 59-65.

[22] Green, T.C. and Jame, R. (2011). Strategic trading by index funds and liquidity provision around S\&P 500 index additions. Journal of Financial Markets, Vol. 14 No. 4, 605-624.

Hair Jr, Joseph F, Black, William C., Babin, Barry J. , dan Anderson, Rolph E. (2014). Multivariate Data Analysis, 7th edition. Essex: Pearson International.

[24] Haw, I.-M., Qi, D. and Wu, W. (2001). The nature of information in accruals and cash flows in an emerging capital market: the case of China. The International Journal of Accounting, Vol. 36 No. 4:391-406.

[25] Hellström, K. (2006). The value relevance of financial accounting information in a transition economy: the case of the Czech Republic. European Accounting Review, Vol. 15 No. 3:325-349.

[26] Jensen, M.C. and Meckling, W.H. (1976), "Theory of the firm: managerial behavior, agency costs and ownership structure", 
Journal of Financial Economics, Vol. 3 No. 4, pp. 305-360.

[27] Ji, X., Ahmed, K. and Lu, W. (2015), The impact of corporate governance and ownership structure reforms on earnings quality in China. International Journal of Accounting \& Information Management, Vol. 23 (2):169-198.

[28] Kong, D., Xiao, T. and Liu, S. (2010). Asymmetric information, firm investment and stock prices. China Finance Review International, Vol. 1 No. 1, 6-33.

[29] Kothari, S. P., A. J. Leone, and C. E. Wasley. 2005. Performance matched discretionary accrual measures. Journal of Accounting and Economics 39: 163-197.

[30] Kothari, S.P., 2001. Capital markets research in accounting. Journal of Accounting and Economics 31, 105-231.

[31] Kusumaningtyas, Natasha Giovani dan Nasser, Etty Murwaningsari. (2020). Pengaruh Reputasi Auditor Dan Asimetri Informasi Terhadap Perataan Laba Dengan Komisaris Independen Sebagai Variabel Moderasi. Jurnal Akuntansi Trisakti, Vol. 7(1):139-152.

[32] Landsman, W. and Maydew, A. (2002), "Has the information content of quarterly earnings announcements declined in the past three decades?", Journal of Accounting Research, Vol. 40 No. 3: 797-808.

[33] Lev, B., Ohlson, J. (1982). Market based empirical research in accounting: a review, interpretations, and extensions. Journal of Accounting Research 20 (Suppl.), 249-322.

[34] Liu, Li, Qu, Wen dan Haman, Janto. (2017). Product market competition, state-ownership, corporate governance and firm performance. Asian Review of Accounting, Vol. 26 (1): 6283.

[35] Luan, C.J. and Tang, M.J. (2007). Where is independent director efficacy? Corporate
Governance: An International Review, Vol. 15 No. 4, pp. 636-43

[36] Lymo, G.D. (2014), Assessing the measures of quality of earnings evidence from India. European Journal of Accounting Auditing and Finance Research, 2(6), 17-28.

[37] Machdar, Nera Marinda, Manurung, Adler Haymans, dan Murwaningsari, Etty. (2017). The Effects of Earnings Quality, Conservatism, and Real Earnings Management on the Company's Performance and Information Asymmetry as a Moderating Variable. International Journal of Economics and Financial Issues, 7(2): 309-318.

[38] Mahrani, Mayang dan Soewarno, Noorlailie. (2018). The effect of good corporate governance mechanism and corporate social responsibility on financial performance with earnings management as mediating variable. Asian Journal of Accounting Research, Vol. 3 (1): 41-60.

[39] Malau, Melinda, Etty Murnawingsari, Sekar Mayangsari, dan Titik Aryati. (2019). Pengaruh Opasitas Laba, Asimetri Informasi, Dan Keinformatifan Laba Terhadap Biaya Ekuitas Di Perusahaan Manufaktur. Jurnal Akuntansi Trisakti, Vol 6 No. 1:43-54.

[40] Mandilas, A., Floropoulos, I., Pipiliagkopoulos, M. and Angelakis, G. (2009). EVA reconsidered for the Greek capital market. European Research Studies, Vol. 12 No. 2, pp. 37-54.

[41] Mostafa, Wael. (2016). The value relevance of earnings, cash flows and book values in Egypt. Management Research Review Vol. 39 No. 12:1752-1778.

[42] Murni, H., Yurniwati. and Purta, R. (2015), The effect of intellectual Capital to the value relevance of accounting information based on PSAK convergence to IFRS (manufacture 
firms of Indonesia. Procedia - Social and Behavioral Sciences, Vol. 211, pp. 999-1007

[43] Murwaningsari, E., Utama, S., \& Rossieta, H. (2015). The Combined Effects of Financial Derivatives and Discretionary Accruals on the Value Relevance of Earnings and the Book Value of Equity. Gajah Mada International Journal of Business, 17(2), 179-198.

[44] Murwaningsari, Etty. (2008). Pengujian Simultan : Beberapa Faktor Yang Mempengaruhi Earning Response Coefficient (ERC). Paper ini dipresentasikan pada Simposium Nasional Akuntansi XI. Pontianak.

[45] Ohlson, J.A. (1995), "Earnings, book values and dividends in equity valuation", Contemporary Accounting Research, Vol. 11 No. 2, pp. 661-687.

[46] Qu, X. and Zhang, G. (2015). Value-relevance of earnings and book value over the institutional transition in China: the suitability of fair value accounting in this emerging market. The International Journal of Accounting, Vol. 50 No. 2, pp. 195-223.

[47] Papadaki, A. and Siougle, G. (2007). Value relevance of price, earnings and book values in the Athens Stock Exchange. Managerial Finance, Vol. 33 No. 5, pp. 309-320.

[48] Pirie, S. and Smith, M. (2008). Stock prices and accounting information: evidence from Malaysia. Asian Review of Accounting, Vol. 16 No. 2, 109-133.

[49] Rachmawati, S. (2010). Asimetri Informasi Memoderasi Beban Pajak Tangguhan dan Manajemen Laba (Asymmetric Information Moderates Deferred Tax and Earnings Management). Jurnal Informasi, Perpajakan, Akuntansi Dan Keuangan Publik, 5(1), 41-55.

[50] Ravi, R. and Hong, Y. (2015). Information asymmetry around S\&P 500 index changes. Review of Accounting and Finance, Vol. 14 No. 2, 106-127
[51] Salipadang, Welly, Robert Jao, dan Beauty. (2017). Pengaruh Mekanisme Good Corporate Governance Terhadap Ketepatan Waktu Penyampaian Laporan Keuangan Dan Dampaknya Terhadap Return Saham. Dinamika Akuntansi, Keuangan dan Perbankan, Mei 2017, 83- 101.

[52] Sehgal, Sanjay, and Kumar Bijoy. 2015. "Stock Price Reactions to Earnings Announcements: Evidence from India." Vision: The Journal of Business Perspective 19 (1):25-36.

[53] Siagian, F., Siregar, S.V. and Rahadian, Y. (2013). Corporate governance, reporting quality, and firm value: evidence from Indonesia. Journal of Accounting in Emerging Economie, Vol. 3 No. 1, 4-20.

[54] Siagian, F. T., \& Tresnaningsih, E. (2011). The impact of independent directors and independent audit committees on earnings quality reported by Indonesian firms. Asian Review of Accounting, 19(3), 192-207.

[55] Sir, J., B. Subroto dan G. Chandrarin. (2010). Intellectual Capital dan Abnormal Return Saham (Studi Peristiwa Pada Perusahaan Publik di Indonesia). Paper dipresentasikan pada acara Simposium Nasional Akuntansi XIII, Purwokerto.

[56] Soydemir, G., Verma, R. and Wagner, A. (2017). The asymmetric impact of rational and irrational components of fear index on S\&P 500 index returns. Review of Behavioral Finance, Vol. 9 (3), 278-291.

[57] Suhardianto, N., B. Subroto, dan G. Chandrarin. (2017). Mapping MarketBased Accounting Research in Indonesia: Graphics and Guidelines for Future Research. Asian Journal of Accounting Research 2(1):18-44.

[58] Syed, A.M. \& Bajwa, I.A. 2018. Earnings announcements, stock price reaction and market efficiency - the case of Saudi Arabia. International Journal of Islamic and Middle 
Eastern Finance and Management 11: 416431.

[59] Tamer, E. (2014), Value relevance of accounting information: evidence from an emerging market. Advances in Accounting, Incorporating Advances in International Accounting, Vol. 30, pp. 176-186.

[60] Wiyadi, Rina Trisnawati, Noviana Puspitasari dan Noer Sasongko. (2016). Pengaruh Asimetri Informasi, Leverage Dan Profitabilitas Terhadap Manajemen Laba Riil Pada Perusahaan Manufaktur Di Indonesia. The 3rd University Research Colloquium 2016.

\section{Cite this article as :}

Puji Wibowo, Etty Murwaningsari, "Earnings Quality, Asymmetric Information, and Market Response : Insights from Indonesia", International Journal of Scientific Research in Science and Technology (IJSRST), Online ISSN : 2395-602X, Print ISSN : 23956011, Volume 7 Issue 6, pp. 377-395, NovemberDecember 2020. Available at doi $\quad$ : https://doi.org/10.32628/IJSRST207663

Journal URL : http://ijsrst.com/IJSRST207663 